\title{
THE EFFECT OF THE ARTICHOKE LEAVES EXTRACT ON THE POSTNATAL DEVELOPMENT OF OFFSPRING OF FEMALE RATS WITH THE ALCOHOLIC PLACENTAL DYSFUNCTION
}

\author{
I.M.Ryzhenko, N.Ya.Asadullayeva, G.V.Zaychenko*
}

\author{
National University of Pharmacy \\ Institute of Continuous Education of Specialists in Pharmacy \\ at the National University of Pharmacy*
}

Key words: artichoke leaves extract; Solcoseryl; alcoholic placental dysfunction, postnatal development of infant rats

\begin{abstract}
The experimental research of the artichoke (Cynara scolymus) leaves extract (ALE) influence on the postnatal development of the $I^{\text {st }}$ generation rats born by female rats with the ethanol-induced placental dysfunction (PD) has been conducted. It has been found that the therapeutic and preventive regimen of ALE and the reference medicine Solcoseryl from the $14^{\text {th }}$ to the $19^{\text {th }}$ day of gestation (on the background of introduction of $40 \%$ ethanol solution in the dose of $4 \mathrm{~g} / \mathrm{kg}$ ) reduced the level of death in infant rats: ALE in 2.4 times and Solcoseryl in 1.6 times compared to the untreated control. The medicines studied caused a significant weight gain in rats compared to the control pathology group. From the $1^{\text {st }}$ to $14^{\text {th }}$ days of the experiment the weight gain caused by ALE was more significant. The difference in the efficacy of the medicines was not further observed. Introduction of ALE and Solcoseryl also promoted the correction of pathological deviations in the postnatal development of infant rats. Moreover, ALE showed a higher activity compared to Solcoseryl. Therefore, the data obtained allow to recommend ALE for the preventive correction of alcoholic embryopathy developed on the background of PD.
\end{abstract}

lcoholism is referred to the medical and social risk factors of the placental dysfunction (PD) development. Recently increase of alcohol consumption by pregnant women has been observed; as a result, the number of alcoholic PD development cases increases. For example, official statistical data show that the share of such women in the USA is 3$10 \%$, in Ukraine is about $10 \%$ [4, $7,10]$. It is known that alcohol can cross the placental barrier, accumulate in the amniotic fluid and have not only the embryolethal, teratogenic, but also the general toxic effect on a fetus $[6,8,11]$. It results in formation of the fetal alcoholic syndrome, which is characterized with growth retardation, mainly expressed within the first months and years of the postnatal period, delay in physical and mental development of children, etc. $[3,4,6]$.

A product of the plant origin "Chophytol" (Lab. Rosa-Phytophar- ma, France) containing the artichoke (Cynara scolymus) leaves extract (ALE) is used in obstetrics for prevention and treatment of PD of various genesis $[3,5,9]$. The results of the previous research show that ALE has expressed the gravidoprotective action under acute ethanol intoxication of rats [1].

The aim of the work was to study the effect of ALE on the postnatal development of infant rats of the $1^{\text {st }}$ generation born by female rats with alcoholic PD.

\section{Materials and Methods}

Alcohol-induced PD was initiated with intragastric introduction of $40 \%$ ethanol solution in the dose of $4 \mathrm{~g} / \mathrm{kg}$ to white nonlinear female rats weighting 180$220 \mathrm{~g}$, in the fetal phase from the $15^{\text {th }}$ to the $19^{\text {th }}$ days of pregnancy [2]. The artichoke leaves extract was introduced in the medical and preventive regimen from the $14^{\text {th }}$ to the $19^{\text {th }}$ days of the intragastri-

\footnotetext{
I.M.Ryzhenko - Doctor of Medicine, professor of the Pharmacology Department of the National University of Pharmacy (Kharkiv)

G.V.Zaychenko - Doctor of Medicine, professor, head of the Department of Clinical Pharmacology of the Institute of Continuous Education of Specialists in Pharmacy at the National University of Pharmacy (Kharkiv)
}

gal gestation in the conditionally therapeutic dose of $50 \mathrm{mg} / \mathrm{kg}$, and the reference medicine Solcoseryl (Valleant pharmaceutical Switselend GmbH, batch 827509), a natural medicine as well, was introduced in the dose of $0.56 \mathrm{ml} / \mathrm{kg}$, intravenously following the same scheme. Females rats were kept antepartum to study the postnatal development of the 1-st generation. The new-born rats kept under usual conditions characteristic for this type of animals were observed within 30 days.

Viability and the somatosexual development of the $1^{\text {st }}$ generation offspring were estimated by the following parameters: the level of the postnatal lethality, the body weight dynamics on the $1^{\text {st }}, 4^{\text {th }}, 7^{\text {th }}, 14^{\text {th }}, 21^{\text {st }}$ and $28^{\text {th }}$ days of observation, pinna detachment and hear-coat covering on the $4^{\text {th }}$ day; eruption of incisors on the $7^{\text {th }}$ day; eyes opening on the $14^{\text {th }}$ day; opening of the vagina and testicles lowering on the $30^{\text {th }}$ day.

Statistical analysis of the data obtained was conducted using the parametric methods (Student's t-test with Bonferroni adjustment, the significance value $p \leq 0.05$ ) with 


\section{The effect of the artichoke leaves extract on lethality of infant rats of the first generation born by female rats with the placental dysfunction caused by ethanol introduction}

\begin{tabular}{|l|c|c|c|c|c|}
\hline \multirow{2}{*}{ Group of animals } & \multirow{2}{*}{$\begin{array}{c}\text { Number of infant rats } \\
\text { in total / on the }\end{array}$} & \multicolumn{2}{|c|}{ Lethality on the day of observation, abs., $\%$} & \multirow{2}{*}{$\begin{array}{c}\text { Total lethality, } \\
\text { abs., } \%\end{array}$} \\
\cline { 5 - 6 } & $21^{\text {st }}$ day of observation & $7^{\text {th }}$ day & $14^{\text {th }}$ day & $21^{\text {st }}$ day & \\
\hline Intact animals & $59 / 54$ & $1(1.7 \%)$ & $2(3.4 \%)$ & $2(3.4 \%)$ & $5(8.5 \%)$ \\
\hline Control pathology & $58 / 43$ & $3(5.2 \%)$ & $6(10.5 \%)^{*}$ & $6(10.3 \%)^{*}$ & $15(25.9 \%)^{*}$ \\
\hline ALE, $50 \mathrm{mg} / \mathrm{kg}$ & $65 / 58$ & $1(1.5 \%)$ & $4(6.2 \%)$ & $2(3.1 \%)^{* *}$ & $7(10.8 \%)^{* *}$ \\
\hline Solcoseryl, $0.56 \mathrm{ml} / \mathrm{kg}$ & $61 / 51$ & $2(3.3 \%)$ & $5(8.2 \%)$ & $3(4.9 \%)$ & $10(16.4 \%)$ \\
\hline
\end{tabular}

Notes:

$1)^{*}$ - statistically significant difference in relation to the animals of the intact control group, $p \leq 0.05$;

$2{ }^{* *}$ - statistically significant difference in relation to the animals of the control pathology group, $p \leq 0.05$.

the help of "Statistica 6.0" statistical software package.

\section{Results and Discussion}

The experimental results are given in Table 1.

It has been determined that lethality of infant rats of the intact animals group in the postnatal period increased before the $21^{\text {st }}$ day of observation. The total lethality by the end of the experiment reached $8.5 \%$. Ethanol introduced to the pregnant rat females of the control pathology group resulted in 3 times greater probability of new-born rats lethality at all times of the experiment in relation to the intact control. Therefore, vitality of such new-born rats within one month of the postnatal period is almost 1.3 times lower compared to new-borns of healthy females.
In the group of animals receiving ALE the offspring lethality reduced by an average $2.4 \mathrm{ti}-$ mes compared to the control pathology group and was almost the same as in new-borns of healthy females. At the same time the quantity of dead infant rats born by female rats treated with the reference medicine Solcoseryl was only 1.6 times less than in untreated animals. The lethality index of Solcoseryl was 1.5 times greater than the one of the medicine under research.

Starting from the first day of birth the body weight dynamics was registered (Table 2). The initial body weight of infant rats in the group of the intact control on the first day after their birth was 5.96 g. Fast and considerable increase of weight was observed un- til the $30^{\text {th }}$ day of the experiment. On the background of the prenatal alcoholization of pregnant females the weight of infant rats probably reduced starting from the $1^{\text {st }}$ to the $30^{\text {th }}$ day of the postnatal development compared to the group of healthy animals. Thus, on the $1^{\text {st }}$ and the $4^{\text {th }}$ day of observation it was $1.34 \mathrm{~g}$ less; on 7 the ${ }^{\text {th }}$ day $1.87 \mathrm{~g}$ less, on the $14^{\text {th }}$ day $-4.94 \mathrm{~g}$ less, on the $21^{\text {st }}$ day -9.52 g less, on $30^{\text {th }}$ day $-14.7 \mathrm{~g}$ less. Besides, increase of the body weight of infant rats in the control pathology group was slower than in animals of the intact control group.

The body weight of infant rats born by female rats receiving ALE was almost the same as of infant rats of intact animals. Introduction of Solcoseryl also resulted in probable increase of the body weight

Table 2

\begin{tabular}{|c|c|c|c|c|c|}
\hline Day & $\begin{array}{l}\text { Group of } \\
\text { animals }\end{array}$ & Intact animals & Control pathology & $\mathrm{ALE}, 50 \mathrm{mg} / \mathrm{kg}$ & Solcoseryl, $0.56 \mathrm{ml} / \mathrm{kg}$ \\
\hline $1^{\text {st }}$ & \multirow{6}{*}{ 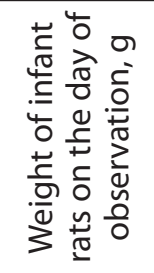 } & $5.96 \pm 0.06$ & $4.62 \pm 0.08^{*}$ & $5.76 \pm 0.07^{* *} / * * *$ & $5.39 \pm 0.05^{* *}$ \\
\hline $4^{\text {th }}$ & & $7.98 \pm 0.12^{x}$ & $6.62 \pm 0.11^{\mathrm{X} / *}$ & $7.38 \pm 0.08^{\mathrm{x}} / * * / * * *$ & $7.10 \pm 0.08^{x} / * *$ \\
\hline $7^{\text {th }}$ & & $10.31 \pm 0.18^{x}$ & $8.44 \pm 0.20^{\mathrm{X} / *}$ & $9.58 \pm 0.15^{\mathrm{X} / * *} / * * *$ & $9.06 \pm 0.15^{x} / * *$ \\
\hline $14^{\text {th }}$ & & $19.04 \pm 0.42^{x}$ & $14.10 \pm 0.44^{\mathrm{X} / *}$ & $19.14 \pm 0.37^{x} / * * * * * *$ & $17.64 \pm 0.42^{x / * *}$ \\
\hline $21^{\text {st }}$ & & $31.73 \pm 0.62^{x}$ & $22.21 \pm 0.61^{x / *}$ & $30.11 \pm 0.62^{x} / * *$ & $29.93 \pm 0.63^{x} / * *$ \\
\hline $30^{\text {th }}$ & & $49.70 \pm 0.86^{x}$ & $35.02 \pm 0.89^{\mathrm{X} / *}$ & $48.53 \pm 0.87^{* *}$ & $47.88 \pm 0.85^{x} / * *$ \\
\hline
\end{tabular}

Notes:

1) ${ }^{x}$ - statistically significant difference in relation to the first day, $p \leq 0.05$;

$2)^{*}$ - statistically significant difference in relation to the animals of the intact control group, $\leq 0.05$;

3 ) ** - statistically significant difference in relation to the animals of the control pathology group, $\mathrm{p} \leq 0.05$;

4) ${ }^{* * *}$ - statistically significant difference in relation to the animals injected with Solcoseryl, $p \leq 0.05$. 
Table 3

\section{The effect of the artichoke leaves extract on the physical development indices of infant rats of the first generation born by females with the placental dysfunction caused by ethanol introduction $(n=59)$}

\begin{tabular}{|c|l|c|c|c|c|}
\hline $\begin{array}{c}\text { Day of } \\
\text { observation }\end{array}$ & \multicolumn{1}{|c|}{ Group of animals } & Intact animals & $\begin{array}{c}\text { Control } \\
\text { pathology }\end{array}$ & $\begin{array}{c}\text { ALE, } \\
50 \mathrm{mg} / \mathrm{kg}\end{array}$ & $\begin{array}{c}\text { Solcoseryl, } \\
0.56 \mathrm{ml} / \mathrm{kg}\end{array}$ \\
\hline \multirow{2}{*}{$4^{\text {th }}$} & $\begin{array}{l}\text { Appearance of the primary } \\
\text { hair-covering, } \%\end{array}$ & 23.7 & $10.3^{*}$ & $23.1^{* *}$ & $18.0^{* *}$ \\
\cline { 2 - 6 } & Pinna detachment, \% & 73.0 & $24.0^{*}$ & $72.3^{* *}$ & $70.5^{* *}$ \\
\hline $7^{\text {th }}$ & Eruption of incisors, \% & 88.0 & $58.0^{*}$ & $89.1^{* *} /^{* * *}$ & $79.7^{* *}$ \\
\hline $14^{\text {th }}$ & Eyes opening, $\%$ & 14.1 & $4.1^{*}$ & $13.3^{* *}$ & 9.3 \\
\hline \multirow{2}{*}{$30^{\text {th }}$} & Testicles lowering, $\%$ & 92.3 & $56.5^{*}$ & $86.7^{* *}$ & 73.1 \\
\cline { 2 - 6 } & Opening of the vagina, $\%$ & 89.3 & $50.0^{*}$ & $82.1^{* *} /^{* * *}$ & 68.0 \\
\hline
\end{tabular}

\section{Notes:}

$1)^{*}$ - statistically significant difference in relation to the animals of the intact control group, $p \leq 0.05$;

$2)^{* *}$ - statistically significant difference in relation to the animals of the control pathology group, $p \leq 0.05$;

$3)^{* * *}$ - statistically significant difference in relation to the animals injected with Solcoseryl, $p \leq 0.05$.

in relation to prenatally alcoholized offspring. Compared to Solcoseryl ALE resulted in more significant increase of the body weight from the $1^{\text {st }}$ to $14^{\text {th }}$ day of the experiment. During the further observation till the $30^{\text {th }}$ day of life the difference between the medicines by this index was leveled.

Preventive introduction of ALE resulted positively on the rates of somatosexual development of infant rats. The corresponding indices are given in Table 3 .

Unlike healthy animals the physiological signs of development significantly slowed down in infant rats of the control pathology group. Under the action of ALE and Solcoseryl development indices of infant rats achieved physiological norms, and were the same as the indices of the intact animals under research. At the same time Solcoseryl was probably inferior compared to ALE, resulting in reduction of the number of infant rats with delay of indices of somatic (eruption of incisors) and sexual (opening of the vagina) development.

Thus, introduction of alcohol to female rats during pregnancy results in a high index of lethality in new-born rats and delay of their postnatal development. The medicine studied (ALE and Solcoseryl) show the fetoprotective effect under conditions of the perinatal impact on the offspring of females with alcoholic PD.

\section{CONCLUSIONS}

1. A positive effect of the artichoke leaves extract and Solco- seryl on the indices of the postnatal development of infant rats of the first generation (lethality, body weight, physical development) has been determined on the model of the placental dysfunction caused by the prenatal ethanol intoxication.

2. The artichoke leaves extract accelerates the somatosexual state of the first generation offspring by such parameters as eruption of incisors, opening of the vagina and has an advantage over the reference medicine Solcoseryl.

3. The results obtained allow to recommend the artichoke leaves extract to be used in complex therapy for preventing the fetal alcoholic syndrome as a complication of the alcoholic placental dysfunction.

\section{REFERENCES}

1. Асадуллаєва Н.Я., Риженко І.М., Зайченко Г.В. // Вісник фармації. - 2011. - №2 (66). - С. 78-81.

2. Доклінічне вивчення лікарських засобів, призначених для лікування плацентарної дисфункції: Метод. рекоменд. / Уклад.: Л.В.Яковлєва, Г.В.Зайченко, А.Г.Ципкун та ін. - К.: ДФЦ МОЗ Украӥни, 2009. - 59 c.

3. Логутова Л.С., Новикова С.В. // Рос. вестник акушера-гинекол. - 2004. - Т. 4, №5. - С. 44.

4. Лук'янова О.М., Резніченко Ю.Г., Антипкін Ю.Г. та ін. Перинатальні проблеми великого промислового міста України. - Запоріжжя: Просвіта, 2007. - 356 с.

5. Пересада О.А., Писаренко Е.А. // Мед. новости. - 2007. - №10. - С. 47-50.

6. Стрижаков А.Н., Тимохин Т.Ф., Баев О.Р. // Вопросы гинекол., акушерства и перинатол. - 2003. T. 2, №2. - C. 53-63.

7. Balachova T.N., Bonner B.L., Isurina G.L., Tsvetkova L.A. // Subst use misuse. - 2007. - Vol. 42, №5. P. 881-894. 
8. Henderson J., Ulrik K., Gray R. // J. of Epidemiol. and Community Health. - 2007. - Vol. 61. - P.1069-1073.

9. Juzyszyn Z., Czerny B., Pawlik A., Drozdzik M. // Mol. Nutr. Food Res. - 2008. - Vol. 52, №5. - P. 589-594.

10. Kelly Y., Sacker A., Gray R. et al. //Intern. J. of Epidemiol., Advance Access. - 2008; doi:10.1093/ije/dyn230

11. Ornoy A., Ergaz Z. // Int. J. Environ. Res. Public Health. - 2010. - Vol. 7, №2. - P. 364-379.

\title{
ВПЛИВ ЕКСТРАКТУ З ЛИСТЯ АРТИШОКУ ПОЛЬОВОГО НА ПОСТНАТАЛЬНИЙ РОЗВИТОК ПОТОМСТВА ВІД САМОК ЩУРІВ 3 АЛКОГОЛЬНОЮ ПЛАЦЕНТАРНОЮ ДИСФУНКЦІЄЮ
}

І.М.Риженко, Н.Я.Асадуллаєва, Г.В.Зайченко*

Національний фармацевтичний університет, Інститут підвищення кваліфікації спеціалістів фармації Національного фармацевтичного університету*

Ключові слова: екстракт з листя артишоку польового; солкосерил; алкогольна плацентарна дисфункція; постнатальний розвиток шурят

\begin{abstract}
Проведено експериментальне дослідження впливу екстракту з листя артишоку польового (ЕЛАП) на постнатальний розвиток щурів I-го покоління, народжених від самок з алкогольною плацентарною дисфункцією (АПд). Встановлено, що ЕЛАП та препарат порівняння солкосерил на тлі введення самкам щурів 40\% розчину етанолу в дозі 4 г/кг в лікувально-профілактичному режимі з 14-го по 19-й день гестації сприяли зниженню летальності щурів: ЕЛАП в 2,4 рази, а солкосерил в 1,6 рази в порівнянні з нелікованими тваринами. Досліджувані препарати викликали вірогідне зростання маси тіла шурів в порівнянні з контрольною патологією. 3 1-го по 14-й день експерименту прослідковувався більш значний приріст маси тіла щурів під впливом ЕЛАП. В подальшому різниці в дії препаратів не спостерігалося. Введення ЕЛАП та солкосерилу також сприяло корекції патологічних відхилень в постнатальному розвитку шурів. При даних умовах ЕЛАП проявляв більшу активність, ніж солкосерил. Отримані дані дозволяють рекомендувати ЕЛАП з метою використання в акушерстві для превентивної корекції фетального алкогольного синдрому, який розвивається на тлі АПД.
\end{abstract}

\section{ВЛИЯНИЕ ЭКСТРАКТА ИЗ ЛИСТЬЕВ АРТИШОКА ПОЛЕВОГО НА ПОСТНАТАЛЬНОЕ РАЗВИТИЕ ПОТОМСТВА САМОК КРЫС С АЛКОГОЛЬНОЙ ПЛАЦЕНТАРНОЙ ДИСФУНКЦИЕЙ}

И.М.Рыженко, Н.Я.Асадуллаева, А.В.Зайченко*

Национальный фармацевтический университет, Институт повышения квалификации специалистов фармации Национального фармацевтического университета *

Ключевые слова: экстракт из листьев артишока полевого; солкосерил; алкогольная плацентарная дисфункция; постнатальное развитие крысят

\begin{abstract}
Проведено экспериментальное исследование влияния экстракта из листьев артишока полевого (ЭЛАП) на постнатальное развитие крысят I-го поколения, родившихся от самок с алкогольной плацентарной дисфункцией (АПД). Установлено, что ЭЛАП и препарат сравнения солкосерил на фоне введения самкам крыс 40\% раствора этанола в дозе 4 г/кг в лечебно-профилактическом режиме с 14-го по 19-й день гестации способствовали снижению летальности крысят: ЭЛАП в 2,4 раза, а солкосерил в 1,6 раза по сравнению с нелеченными животными. Изучаемые препараты вызывали достоверное повышение массы тела крысят в сравнении с контрольной патологией. С 1-го по 14-й дни эксперимента прослеживался более значительный прирост в массе тела крысят под влиянием ЭЛАП. В дальнейшем разницы в действии препаратов не наблюдалось. Введение ЭЛАП и солкосерила также способствовало коррекции патологических отклонений в постнатальном развитии крысят. При этом ЭЛАП проявлял большую активность, чем солкосерил. Полученные данные позволяют рекомендовать ЭЛАП для применения в акушерстве с целью превентивной коррекции фетального алкогольного синдрома, который развивается на фоне АПД.
\end{abstract}

Address for correspondence:

53, Pushkinska str., Kharkiv, 61002, Ukraine

Tel. (57) 706-30-69. E-mail: meln@ukrfa.kharkov.ua.

National University of Pharmacy 